
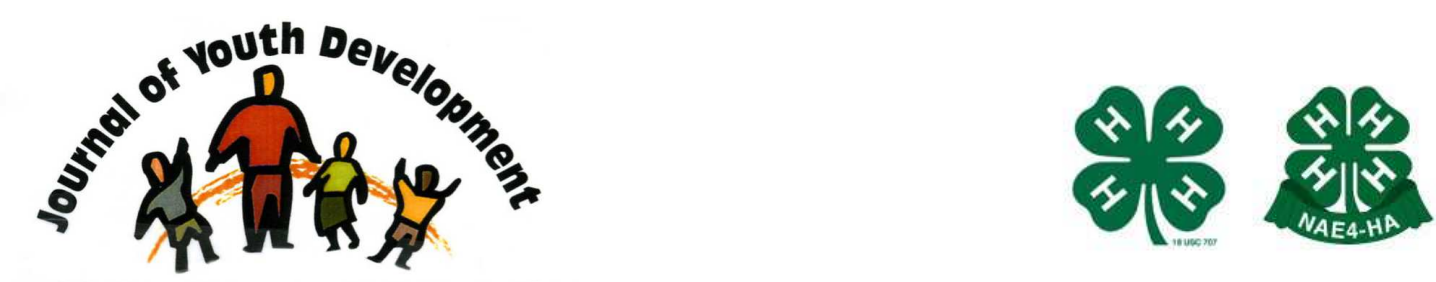

Bridging Research \& Practice

\title{
Cross-Cultural Understanding Through Youth Sports: Bridging the Tolerance Gap Through Youth Development
}

\author{
Craig M. Ross \\ Department of Recreation, Park and Tourism Studies \\ Indiana University \\ cmross@indiana.edu \\ Lynn M. Jamieson \\ Department of Recreation, Park and Tourism Studies \\ Indiana University \\ Donald W. Mitchell \\ Indiana Center for Cultural Exchange \\ Purdue University
}




\title{
JOURNAL OF YOUTH DEVELOPMENT \\ bridging research and practice

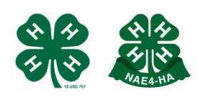

Volume 3, Number 3, Winter 2008

Article 080303PA002

\section{Cross-Cultural Understanding Through Youth Sports: Bridging the Tolerance Gap Through Youth Development}

\author{
Craig M. Ross and Lynn M. Jamieson \\ Indiana University \\ Donald W. Mitchell \\ Purdue University
}

\begin{abstract}
The USPORT-Kyrgyzstan project was an ambitious initiative of public diplomacy, sports diplomacy, cross-cultural exchange, incountry grassroots projects, and international cooperation. The project consisted of three phrases which included youth recreational sport programming, youth leadership and development training, and youth tolerance training. Overall, it proved to be an extremely effective form of intervention that provided youth in this region of the Middle East with many positive and constructive youth sports and leadership development opportunities.
\end{abstract}

\section{Introduction}

In the aftermath of $9 / 11$, many changes took place that increased security measures, examined groups of individuals and their purposes for travel, and improved the perceived safety of those who gathered for events, travel, and other means. The wake of 9/11 also brought increased interest on the part of the State Department of the United States to help stabilize societies and develop programs designed to become more aware of a sector of the world that is little understood - the Islamic nations of the Middle East (Dunne, 2004; Powers, 2006).

With this desire to understand came many forms of cross-cultural exchange, the extent to which has provided opportunities on university campuses to look at unique needs of Middle East nations. One such need was identified in the area of youth recreational sport development. In 
particular, how recreational sport can serve as a form of intervention to provide at-risk youth in these countries with positive and constructive environments and opportunities other than those that plague these nations such as poverty, lack of education, alcohol, drug, terrorism and other abuse (Fraser-Thomas, Cote, \& Deakin, 2005; Rustad, n.d.). The United Nations further suggests that "by its very nature, sport is about participation. It is about inclusion and bridging cultural or ethnic divides. Sport can cut across barriers that divide societies, making it a powerful tool to support conflict prevention and peace-building efforts. When applied effective, sport programmes promote social integration and foster tolerance, helping to reduce tension and generate dialogue" (UN Inter-Agency Task Force on Sport for Development and Peace, 2005). In addition, youth sport activities are frequently associated with positive experiences related to developing teamwork skills and forming community ties (Hansen, Larson, \& Dworkin, 2003).

\section{Program Overview}

The Indiana Center for Cultural Exchange (ICCE) was created by academic and administrative leaders at Indiana University, Purdue University, and the University of Notre Dame in order to bridge mutual understanding, appreciation, and cooperation between the United States and the Muslim world through youth sports development. The ICCE also included the Indiana-based Islamic Society of North America (ISNA) and eventually expanded to include the University of Chicago, University of Minnesota, and noted national and international organizations.

The mission of the ICCE is to utilize its vast resources in ambitious initiatives of:

- public diplomacy,

- sports diplomacy,

- cultural exchange,

- in-country projects, and

- international cooperation.

The ICCE completed a very successful sports diplomacy project/program entitled: Unity through Sport (USPORT) or USPORT-Kyrgyzstan.

USPORT-Kyrgyzstan included Indiana University, Purdue University, the University of Notre Dame, Mercy Corps, and NIKE. The objective was to create youth recreational sports leagues throughout the Nookat region of the Kyrgyz Republic and included three major components in its "train the trainer" program. These components included:

(1) youth recreational sports management, coaching, and officiating training,

(2) youth leadership and development training, and

(3) youth tolerance training.

A three-person faculty project team from the ICCE universities visited Kyrgyzstan in early 2005. The team spent two days in the capital Bishkek and four days in Osh, the second largest city. Most of the time in Osh was spent visiting the Nookat region where the USPORT project was located. The Nookat region is located south and west of Osh, has about 220,000 inhabitants, and forms part of the Ferghana Valley that extends into both Uzbekistan and Tajikistan.

Because of a number of destabilizing factors in these areas, including a multi-ethnic population, a recent history of violent conflicts, inter-village and cross border tensions, economic decline and unemployment, and environmental degradation, this region is constantly at risk for conflict. 
Also in this context, youth age $0-14$, who now make up about $30 \%$ of the population, are especially vulnerable to the recruitment for, and provocation by, radical religious ideologies that support terrorism activities. In addition, youth are also succumbing to problems with alcohol, tobacco, and other drugs due to extreme poverty, lack of education, and unemployment (Choudhury, Denham, Kumser, \& Romanelli, 2002).

The U.S. State Department's USPORT program for the Kyrgyz Republic sought to address the risk for conflict and radical influence by promoting constructive programs in the region. The goal of these programs was to assist in the prevention or reduction of stereotyping, violence, and hatred, particularly among youth, that is prevalent in the Nookat region of Osh Oblast.

Together, with a representative from its local partner in Kyrgyzstan, Mercy Corps International, the USPORT team visited a number of key institutions and influential individuals to solicit their support for the project and to make an assessment of the sports facilities in Nookat. The team also interviewed 42 applicants that included sport coaches, physical education teachers and NGO representatives from Nookat, and chose 10 candidates and 4 alternates to visit the three Indiana universities for training in the various dimensions of the USPORT program.

In designing the USPORT project, we asked ourselves a number of questions that fell into three categories:

1. How can we reach the largest number of youth? How can we bring into our project the most marginalized and disenfranchised youth who are most at risk of violence or being recruited into organizations and movements dedicated to violent change?

2. How can we develop as many youth as possible in positive ways and involve them in community projects? How can we identify and develop key youth who have the potential to be future leaders?

3. How can we teach youth to be tolerant of ethnic and cultural differences? How can we teach youth to value religious differences?

In regard to the first set of questions, we concluded that the best way of reaching a large number of youth is through a youth recreational sports program. Sports programs have proven to help youth establish peaceful and productive relations with their neighbors (Colliard, \& Henley, 2005; Holden, \& Wilde, 2004; Saskatchewan Culture, Youth and Recreation, 2003; United Nations, 2005). They have been shown to be highly successful for building bridges, fostering community involvement and creating friendships among youth (Perks, 2007). The team approach in sports leagues connects youth from different ethnic backgrounds. It helps atrisk youth gain a sense of belonging, experience the importance of teamwork and cooperation first hand, and value fellowship that crosses traditional boundaries (Autry, \& Anderson, 2007). Further, Mercy Corps has found that its own recreational sports programs in the Ferghana Valley were particularly valuable in reaching out to some of the more marginalized youth who would not attend more discussion-based or technical activities. We also saw sports programs as a way of connecting youth, especially those who are at most risk, to their local communities, making them less vulnerable to leaving home to join outside organizations.

In regard to our second set of questions, youth recreational sports programs are not just single events, but ongoing activities in the context of which youth leadership and development training can take place. Sports have always been a vehicle for leadership development that 
carries over off the playing field into the rest of one's life (Martin, 2004; Mull, Bayless, \& Jamieson, 2005). Youth development in general can enable young people to develop a sense of responsibility, more self-confidence, a sense of value in the eyes of others, social skills such as cooperation, assertion, and responsibility, and a greater value to positive and productive relationships with others (Cote, 2002; Eccles, \& Templeton, 2002; NAYS, 2002; Wright, \& Cote, 2003). Youth leadership training in particular gives young people the skills needed to analyze issues, suggest solutions, and resolve conflicts in peaceful ways that contribute to unity within and between communities. Leadership training helps youth identify and discuss local issues relating to young people as well as teaching them communication skills needed to present their views to the elders of the community. In addition, leadership training can assist youth in developing and participating in local civic activities in ways that help the youth feel valued and bonded to their community (NAYS, 2002; Wilson, 2000).

Lastly, we concluded that a youth tolerance training component was necessary for our project. This component has two aspects.

- First, we focused on training youth in ethnic tolerance, conflict mitigation, and peacebuilding. Greater tolerance, acceptance of others, mutual understanding, and respect are key to the development of cooperation between persons of different ethnic backgrounds. This kind of cooperation is fundamental to peaceful change in multiethnic regions.

- $\quad$ Second, we included training in religious tolerance, in valuing other religious traditions. While all the youth in the region of Osh are Muslims, they are sometimes influenced by radical views that demonize other religions, especially Christianity and Judaism. Training in religious tolerance make youth less likely to be convinced by the extremist religious ideology of those who would propose violence against persons of other faiths in the broader international arena (Reshef, \& Paltiel, 1989).

Given our resources and our conclusions concerning the design of a viable project proposal, we decided to offer multifaceted professional training that would lessen the potential for ethnic conflict in the Osh region. We created and developed youth recreational sport programs that included strong youth development, leadership, and tolerance components. This was presented to the 14 adult trainers who were selected to implement programs across the region.

We believe that this program will build grassroots friendship, teamwork, and cooperation; selfesteem, leadership, community action, and connectedness; as well as mutual understanding, respect, and tolerance. The development of these qualities and activities will serve to reduce the potential for conflict within and between communities in the Osh region, and making youth less receptive to extremist influences.

\section{Project Description Detail}

The USPORT project had three components to its train-the-trainer program at the three ICCE universities:

\section{Youth Recreational Sports Management and Coaching Training}

The USPORT project included a two-week short course at Indiana University in recreational sports management, programming, coaching, and officiating with the following objectives:

- train trainers to organize, plan, manage and program recreational sports programs, 
- train trainers in specific sports coaching in soccer, basketball and women's volleyball, as well as rules and officiating in these sports.

To achieve these objectives, the USPORT short course was divided into two, five-day segments. During the first week, the participants were trained in the following:

- settings for recreational sports and the leisure sports model,

- planning, controlling, and managing of recreational sports programs,

- programming and supervision of sport tournaments and sports clubs,

- physical, psychological, and cultural impact of youth recreational sports programs.

During the second week, the participants were trained in the following:

- coaching basics, skill development, and rules and officiating in soccer, basketball and women's volleyball.

\section{Youth Leadership and Development Training}

The youth leadership and development training segment of USPORT took place at Purdue University. Its training program was designed to develop the particular knowledge, qualities, and skills youth need to become effective leaders within culturally diverse communities. To help create young leaders and role models who will work with their peers to instill positive values, the youth leadership/development component of USPORT included the following objectives:

- to teach the trainers an effective youth leadership development program to use with youths in Kyrgyzstan in order for youth to learn social life-skills and positive values that will enhance the well-being of themselves, their families, and their communities,

- to enable trainers to teach youths to be creative and resourceful in dealing with problems, to teach them communication skills, encourage them to have a vocal presence on social issues, and empower them to work with their peers in grassroots community projects,

- to help trainers build self-esteem, self-confidence, self-discipline, and social responsibility among youth,

- to train trainers to build youth-youth and youth-adult relationships across socioeconomic, cultural, ethnic, and geographic lines within and between communities.

\section{Youth Tolerance Training}

Tolerance training for USPORT was conducted at the University of Notre Dame's Kroc and Kellogg Institutes and at the Islamic Society of North America. The objectives were:

- to understand better the dynamics of ethnic conflict and the need and goals for tolerance training and peace-building in the midst of ethnic conflict,

- to give the trainers ways and suggestions of working with youth in order to develop ethnic tolerance and a desire for peace-building,

- to help address the radial religious ideology that demonizes other religions, especially Christianity and Judaism. 


\section{USPORT in the Kyrgyz Republic}

Lastly, as part of the USPORT program, Mercy Corps partnered with ICCE and the 14

trainers in order to achieve the following USPORT objectives in the Kyrgyz Republic:

- improve levels of tolerance and understanding among youth in the Nookat area of the Osh region through active participation in youth recreational sports programs and joint problem-solving activities,

- enable these young people to participate in sports leagues, game days and related sports activities with their neighboring communities,

- coach these young people in soccer, basketball and women's volleyball,

- present to these young people the USPORT programs in tolerance and youth development and leadership,

- improve basic community social infrastructure through small, grassroots-driven projects that young people will design and implement based on their participation in the programs.

With the support of Mercy Corps and the Kyrgyz Ministry of Sport, the 14 Kyrgyz USPORT trainers trained other coaches, referees, and recreation supervisors in Kyrgyzstan. Together they created, organized, managed, coached, and officiated youth recreational sports leagues, game days and tournaments in the Nookat region for the remainder of 2005 and 2006. In that context, they presented programs, called "Time Out for Unity," to assist youth in developing tolerance, leadership, character, and engaging in community service.

The USPORT project brought in almost 2,000 youth, both boys and girls in separate leagues. Over 800 youth took part in the final tournament in late 2005 and early 2006. The local authorities and benefactors have taken over the leagues from Mercy Corps and have expanded them to include more villages in the region.

\section{In their own words...}

The following quotes, obtained through interviews from trainers in the program as well as youth participants after USPORT was implemented in Kyrgyzstan, demonstrate the impact that USPORT-Kyrgyzstan is having on league players, trainers, and supporters in Kyrgyzstan:

"During the games, a great number of fans enthusiastically support their teams. Players have started to see in their rivals not only opponents, but also friends. During the process of league play, children have already become closer and more friendly, and have even begun to greet and recognize each other in the streets. This is not insignificant."(USPORT Train the Trainer basketball coach at the Abduvaitov School)

"Our trainer is very kind and he trains well. I requested him to let me play on this team because I'll do anything to play more soccer. And it's fun to mix with other children!" (a student of Krupskaya School)

"One phenomenon worth noting is parent attendance at leagues games. Prior to USPORT league play, it was uncommon for Nookat parents to attend their children's sports events, primarily because parents had few opportunities to cheer for their 
children. Though fans are still few, the noticeable increase in parental involvement in the sports league is a positive start." (USPORT Train the Trainer volleyball coach)

"Today I held a 'Time Out for Unity' exercise for the first time in front of a large crowd of people. Of course, I was nervous at the beginning, but once I started it became easier as the audience was active and worked with me well. I have prepared some materials for this training using US training handouts and the advice of our trainer, Janybai (USPORT Train the Trainer participant). "(Volunteer and student from Tajibai School)

"I held a number of 'Time Out for Unity' exercises during league basketball and football games. Initially, the issue of tolerance among children was difficult to get across as kids were so focused on winning. Regardless, it's so important to think beyond winning and losing and focus on the more important issue: to make friends with the other participants. These trainings help, and the relationships between the children are improving. They understand that these games were organized to build friendship and strengthen them further. As a result of the 'Time Out for Unity' exercises, players are now congratulating each other after the game and showing more sportsmanship while playing. "(USPORT Train the Trainer coach at the Krupskaya school)

"As result of the USPORT organized referee trainings, youth between the ages of 14-17 - still just students at school - are now refereeing together with adults. Usually they are paired, with one referee being an adult and one being a young person. (USPORT Train the Trainer participant)

\section{Conclusion}

USPORT's impact was captured through the number of participants, trainings, and service projects that were carried out, as well as through reported changes in perceptions and attitudes about inter-ethnic friendships and tolerance of ethnic differences. With completion in 2006, USPORT-Kyrgyzstan had met or was close to meeting all of its expected benchmarks. Overall, the project:

1) trained 14 Kyrgyz USPORT trainers,

2) formed 98 sports teams directly benefiting 1,176 youth participants,

3) had $50 \%$ female participants, $65 \%$ ethnically Kyrgyz participants and $35 \%$ ethnically Uzbek participants,

4) directly benefited 2,842 adults, and

5) developed one grassroots service project in each of the seven hubs in Kyrgyzstan.

Kvalsund (2005) reminds us that sports, with its unique power can "bring people together and create communication where this has been removed and to strive for a positive change of people's attitudes." More than 40 years ago, DeGrazia, a leisure scholar, suggested that "recreation as a part has a vital mission in today's world. In an age of 'Hot and Cold' war, widespread international unrest, and terrifying weapons capable of blotting out whole cities at the flick of a button...recreation and sport must contribute effectively to the cause of peace" (1964). 
Creating youth sport programs for at-risk youth involves using sport as a strategy or vehicle to strengthen youth learning and development. These programs incorporate specific rules for playing the sport, group interactions within the team and league and outside of the community, city or village, and provide a sense of unity among the participants who come with culturally different backgrounds. The United Nations regards sport as an effective tool and a strong unifying factor in the process of conflict transformation and peace building. "The balance between developing sport in its traditional form and using sport to achieve peaceful coexistence can only be managed by conscious and planned implementation, increased research, concept development and understanding and increased training of field implementers" (Kvalsund, n.d.). We believe that the USPORT program had tremendous results for this region and could certainly be replicated in other parts of the world where youth are at risk. Truly, recreational sport can serve as a form of intervention and as a form of peace building that can provide at-risk youth a future for tomorrow.

\section{References}

Autry, C. E., \& Anderson, S.C. (2007). Recreation and the Glenview Neighborhood: Implications for youth and community development. Leisure Sciences, 29, 267-285.

Choudhury, B., Denham, T., Kumser, A., \& Romanelli, A. (2002, October). Kyrgyzstan: A risk assessment brief. Country Indicators for Foreign Policy, Carleton University.

Colliard, C., \& Henley, B. (2005, December). Overcoming trauma through sport. Paper presented at the $2^{\text {nd }}$ Magglingen Conference-Sport and Development, Magglingen, Switzerland.

Cote, J. (2002). Coach and peer influence on children's development through sport. In J. M. Silva \& D. E. Stevens (Eds.), Psychological foundations of sport (520-540). Boston, MA: Allyn \& Bacon.

Cote, J., \& Hay, J. (2002). Children's involvement in sport: A developmental perspective. In J.M. Silva \& D.E. Stevens (Eds.) Psychological foundations of sport (484-502). Boston, MA: Allyn \& Bacon.

DeGrazia, S. (1964). Of time, work and leisure. New York: Doubleday-Anchor.

Dunne, M. (2004, October). Integrating democracy promotion in U.S. Middle East policy. Carnegie Endowment for International Peace, Carnegie Paper No. 50.

Eccles, J., \& Templeton, J. (2002). Extracurricular and other after-school activities for youth. Review of Education, 26, 113-180.

Fraser-Thomas, J.L., Cote, J., \& Deakin, J. (2005). Youth sport programs: An avenue to foster positive youth development. Physical Eucation and sport Pedagogy, 10(1), 19-40.

Hansen, D.M., Larson, R.W., \& Dworkin, J.B. (2003). What adolescents learn in organized youth activities: A survey of self reported developmental experiences. Journal of Research on Adolescence, 13(1), 25-55.

Holden, P., \& Wilde, N. (2004, July). Defense or attack? Can soccer clubs help tackle social exclusion? Paper presented at the ISTR Sixth International Conference, Toronto, Canada. 
Kvalsund, P. (n.d.). Sport and Peace Building. Retrieved January 18, 2008, from http://www.toolkitsportdevelopment.org

Kvalsund, P. (2005, December). Sport as a tool for peace-building and reconciliation. Paper presented at the $2^{\text {nd }}$ Magglingen Conference on Sport and Development, Magglingen, Switzerland.

Martin, R. (2004). Successful coaching ( ${ }^{\text {rd }}$ ed.). Champaign, IL: Human Kinetics.

Mull, R.F., Bayless, K.G., \& Jamieson, L.M. (2005). Recreational sport management (4 ${ }^{\text {th }}$ ed.). Champaign, IL: Human Kinetics.

NAYS, (2002). Recommendations for communities: National summit on raising community standards in children's sports. West Palm Beach, FL: National Alliance for Youth Sports.

Perks, T. (2007). Does sport foster social capital? The contributions of sport to a lifestyle of community participation. Sociology of Sport Journal, 24, 378-401.

Powers, J. (2006). Iraq's youth in a time of war. SAIS Review, 26, 17-28.

Rustad, S.A. (n.d.). Sport as a tool in peace building. Retrieved January 25, 2008, from http://www.sportanddev.org/data/document/document/177.pdf

Reshef, N. \& Paltiel, J. (1989). Partisanship and sport: The unique case of politics and sport in Israel. Sociology of Sport Journal, 6, 305-318.

Saskatchewan Culture, Youth and Recreation. (2003, August). The Impact of Culture/Arts, Sport and Recreation on Antisocial Behavior in Youth: Evidence and Analysis. Strategic Policy and Youth Branch.

UN (2005, February). Enhancing Youth Participation and Action in the Implementation of Copenhagen Declaration of the World Summit for Social Development. Economic and Social Council-Commission on Social Development, Forty-third Session.

UN Inter-Agency Task Force on Sport for Development and Peace, (2005). Sports as a tool for development and peace: Towards achieving the United nations Millennium Development goals. Retrieved January 18, 2008, from http://www.un.org/sport2005/resources/task force.pdf

Wilson, J.J. (2000). Safe from the start: Taking action on Children Exposed to Violence. Washington, DC: U.S. Department of Justice.

Wright, A.D. \& Cote, J. (2003). A retrospective analysis of leadership development through sport, The Sport Psychologist, 17, 268-291.

(C) Copyright of Journal of Youth Development Bridging Research and Practice. Content may not be copied or emailed to multiple sites or posted to a listserv without copyright holder's express written permission. Contact Editor at: patricia.dawson@oregonstate.edu for details. However, users may print, download or email articles for individual use.

ISSN 2325-4009 (Print); ISSN 2325-4017 (Online) 